\title{
PREZIMENA, OSOBNA IMENA, OBITELJSKI I OSOBNI NADIMCI KRIVOPUĆANA
}

\author{
Enver LJUBOVIĆ \\ V. Čopića 1 \\ 53270 Senj
}

\section{UVODNI DIO}

$\breve{Y}_{\text {it }}$ itelji Krivog Puta, Krivopućani, pripadaju primorskoj skupini Bunjevaca-Krmpoćana, a na ove prostore naselili su se tijekom seoba 1605. i 1627. Naselili su se iz zadarskog zaleđa, tj. Podzrmanja u Lič (Gorski kotar) i Krmpote, naselje koje je postojalo pod imenom Sv. Jakov i prije seoba Bunjevaca (usp. Pavličević 1989:155.). Dakle, dio Bunjevaca iz Ravnih Kotara naselio se tijekom seoba u Krmpote, gdje je bilo naselje pod imenom Sv. Jakov i prije seoba Bunjevaca, a dio u Gorski kotar.

Doseljavaju tri skupine, jedna su bili Krmpoćani koje je predvodio Damjan i njegov sinovac Tadija. ${ }^{1}$ Oni su u Hreljinu, u crkvi sv. Jurja, 16. lipnja 1605. položili prisegu vjernosti Zrinskim i Frankopanima, koji su bili feudalni gospodari toga kraja. Oko 1627. dolazi do sukoba Bunjevaca -Krmpoćana sa Zrinskim i Frankopanima, oko posjedovanja zemlje pa se, zbog guste naseljenosti kraja, Bunjevci-Krmpoćani spuštaju prema moru u Sveti Jakov, danas Krmpote, a jedan dio odlazi iz Krmpota preko Alana i Krivog Puta sve do prijevoja Vratnik. (Pavličević 1989:156).

Za ovaj prilog podatke sam sakupljao razgovarajući s pojedinim Krivopućanima (metodom usmene povijesti, kako to nazivaju povjesničari, odnosno tehnikama intervjua, kako to nazivaju etnolozi). Cilj ovoga priloga je prikazati osobne i/ili obiteljske nadimke te osobna imena Krivopućanki i Krivopućana. Također sam naveo i sva prezimena Krivoga Puta i nastojao objasniti njihov postanak s jezičnog aspekta. Sve nadimke klasificirao sam po obiteljima i naseljima (zaselcima). Nakon pregleda građe nastojao sam dati i kratko objašnjenje pojedinog nadimka, svrstati obiteljske nadimke prema kategorijama nastajanja (npr. prema zanimanjima, tjelesnim osobinama, karakternim osobinama). Za pojedine nadimke naveo sam i kratke priče kazivača o razlozima njihova nastanka.

Izuzetno je značajna sklonost Krivopućana, ali i svih primorskih Bunjevaca, davanju nadimaka. Naime, oni se koriste u svakodnevnoj jezičnoj komunikaciji te preuzimaju identifikcijsku ulogu prezimena i imena osobe. Obiteljski nadimci ovoga kraja imaju svoju praktičnu ulogu jer dovode do lakše identifikacije osoba unutar istog sustava prezimena. Nadijevanje nadimaka nije samo hir odredene sredine nego nužnost radi lakše identifikacije osoba (Šimunović 2006: 191).

Obiteljski nadimci su se nasljeđivali, a često su pojedinci, vremenom, u okviru jedne obitelji dobivali osobne nadimke koji su se onda pretvarali u obiteljske.

\section{PREZIMENA, MUŠKA I ŽENSKA IMENA}

\subsection{KRIVOPUTSKA PREZIMENA}

Drezimena su vrlo značajan i koristan pokazatelj koji upućuje na vrijeme i mjesto nastanka pojedine obitelji, odnosno roda. Prezimena krivoputskog kraja uglavnom datiraju s početka 17. stoljeća, a neka nalazimo u razdoblju pred doseljenje Bunjevaca krajem 16. stoljeća, kao npr. prezime Butković i Špalj.

Većina bunjevačkih, pa time i krivoputskih prezimena ustalit će se tek nakon oslobođenja naših krajeva od Osmanlija krajem 17. stoljeća, kada je konačno došlo i do trajnog naseljavanja Bunjevaca na ove prostore.

Od svih krivoputskih obitelji jedino Krmpotići dolaze u Sveti Jakov, danas Krmpote, u prvoj seobi 1605. godine, a sve ostale obitelji doseljavaju se u drugoj seobi 1627. godine, a neke kasnije, kao npr. Burići, Butkovići, Anići, Špalji, Rončevići i Šolići. O seobama Bunjevaca - Krmpoćana opširnije vidi u: Pavličević 1989: 147-170. 
Austrijska carica Marija Terezija (1740.-1780.) naređuje svim državnim službama da moraju popisati sve osobe, sosobnim imenom i prezimenom koje mora biti nasljedno i nepromijenjeno. ( Salopek 2007: 222)

U drugoj seobi Bunjevaca-Krmpoćana 1627. u Krmpota iz Liča ${ }^{2}$ na ovo područje doseljavaju se obitelji: Blaževići ${ }^{3}$, Filipovići, Pavelići, Pavličevići, Peričići, Prpići, Šojati, Špalji, Tomljanovići (Tomljenovići) i Vukelići (opširnije vidi u: Pavelić 1991:21-45, Šarić 2008:15.-43., Pavičić, 1962: 160). ${ }^{4}$

Dakako, značajno je spomenuti da je danas, usprkos površinski velikom području Krivog Puta, prisutno svega 11 prezimena $^{5}$, a najbrojnija prezimena su: Tomljanovići ${ }^{6}$ (Bunica, Butković Dolac, Podbilo, Krivi Put, Vrataruša, Vrtlina, Cigići, Zamalić, Sibinj Krmpotski), Prpići ${ }^{7}$ (Francikovac, Lucići, Judića Gorica, Klarićevac, Krivi Put, Mrzli Dol, Šušanj i Veljun), Krmpotić ${ }^{8}$ i (Veljun Primorski), Šojati (Šojatski Dolac) te Vukelići ${ }^{9}$ (Alan). ${ }^{10}$

Ostala prezimena su: Blaževići (Stanić Brig-Mrzli Dol), Šolići (Podbilo-Šolići), Špalji (Gornji i Donji Špalji), Filipovići (Krivi Put), Rončevići (zaselak Rončevići) i Burići (Serdari).

Danas na području Krivoga Puta postoje rodovski nazivi zaselaka koji su dobili ime po prezimenima, kao npr.: Anići, Burići, Butković Dolac ${ }^{11}$, Pavelići, Rončevići ${ }^{12}$, Šojatski Dolac, Šolići, Špalji ${ }^{13}$ (Gornji i Donji Špalji) i Vukelići ${ }^{14}$.

2 Godine 1633. Bunjevci-Krmpoćani već su u Krmpotama: Nastanjeni do daljega odlučka med Senjem i Ledenicami pri Sv. Jakovu ( Lopašić, II. 1889: 163)

3 Prezime Blažević dolazi od riječi Blaž > grč. Blasios, lat. Blasius, a Blaževa djeca nazvana su Blaževići. Više u: Brodnjak 1992: 146.

4 Od svih gore navedenih obitelji prema vlastitom saznanju i radu na terenu te izjavama nekoliko kazivača krivoputske obitelji, koje i danas obitavaju na ovome području su: Blǎ̌evići, Filipovići, Krmpotići, Prpići, Pavelići i Šojati, a nešto kasnije se doseljavaju Anići, Burići, Butkovići, Rončevići. Šolići i Špalji. Špalji ne pripadaju Bunjevcima, nego su se doselili iz Bribira (Vinodol) i pripadaju staroj autohtonoj hrvatskoj obitelji Vinodola, a potvrdu za to imamo i na starom groblju u Svetom Jakovu (Krmpote), gdje i danas postoji nadgrobna ploča s imenom, dakako, viđenije osobe, Ana Marije Špalj, bez godine rođenja i smrti. Nekoliko članova ove obitelji naselilo se u Krivi Put, gdje su formirali rodovsko naselje (zaselak) Špalji (Gornji i Donji Špalji), te poprimili bunjevački identitet ušavši u bunjevačko naselje. Opširnije vidi u: Pavelić 1991:39-40.

Isti naziv zaselka, na dvije nadmorske visine, nastao je kao posljedica selidbe na ljetne stanove u ljetnim mjesecima. Više vidi u: u prvom svesku Monografije, u prilogu M. Rajković 2008: 159-183.

5 Na temelju terenskog istraživanja utvrdio sam da u Krivome Putu danas živi jedna obitelj po prezimenu Mihelac, koja se doselila iz Slovenije, pa čak ima i obiteljski nadimak Melac te jedna obitelj Tonkovića, koja se doselila iz okolice Otočca u Lici i priženila u obitelj Prpić Mukin te obitelj Hotlovac, iz Kotor Varoši iz (BiH), koja se priženila u obitelj Prpić s nadimkom Šekin. U zaselku Šojatski Dolac živi obitelj Taboga, talijanskog podrijetla koja nosi nadimak Balun jer se Taboga priženio u obitelj Šojat Balun.

6 Prezime Tomljanović (Tomljenović) nastalo je od osobnog imena Thoma koje je aramejskog podrijetla. U grčkom jeziku javlja se u obliku Thomas, a u latinskom Tomas. Opširnije u: Šimunović 2006: 40.

7 Prezime Prpić u osnovi ima glagol prpati> čeprkati, prekapati po nečemu, tražeći nešto, a imenica prpa znači > strah, trta, nevolja. Opširnije u: Brodnjak 1992:459.

8 Šmunović 2006: 137. Bunjevačko i vlaško pleme Krmpote, dalo je ime naselju i oblikovalo prezime Krmpotić. Etimologija prezimena je u vezi s latinskom imenskom osnovom camp(us), tj. oni koji žive u polju.

$9 \quad$ Prezime je nastalo od rodonačelnikova osobnog imena Vukelja ili Vukela koje je izvedenica od narodnoga imena Vuk, a Vukeljini potomci su Vukelići. Postoje dvije nesrodne rodovske zajednice istoga prezimena: a) Vukelići katolici Bunjevci naseljeni uglavnom u senjskom zaleđu (Alan, Jablanac i Krasno) te Lika b) pravoslavni Vukelići (Drežničko polje i Plaški). Opširnije u: Salopek 2007: 452.

10 Po popisu stanovništva Kraljevine Jugoslavije iz 1930. godine u Krivome Putu je po prezimenima živjelo: Blaževića (10 obitelji), Filipovića 2, Krmpotića 56, Prpića 120, Rončevića 5, Šojata 50, Šolića 10, Špalja 21, Tomljanovića 142 i Vukelića 13 obitelji. Opširnije u: Pavičić 1962: 275-290.

11 Godine 1461. kneginja Elizabeta Frankopanka darovala je fratrima samostana sv. Jelene pokraj Senja sjenokošu u Dolcu, a vjerojatno se radi o rodovskom naselju Butković Dolac nedaleko od Vrataruše. Opširnije u: Bogović 2008: 69. Butković Dolac je rodovsko naselje stare hrvatske obitelji Butković. Prezime je nastalo od rodonačelnikova osobnog imena Butko (Budo, Budimir i Budislav), a Butkovi potomci su Butkovići. Prvi put se spominju u ispravi iz 1475. godine Mihovil Butković, vikar samostana sv. Mikule na Gvozdu (pavlinski samostan na Kapeli). Jedna grana ove obitelji je plemićka te posjeduje grb. (Salopek 2007: 288-289)

12 Šimunović 2006: 201. U osnovi ovog prezimena je pridjev h(rom), odnosno imenica h(romac) »čovjek koji hramlje». Ovdje tjelesna mana postaje važan pokazatelj u identifikacije neke osobe. Prezime je nastalo na štokavskom jezičnom području koje u svojem govoru nema glasa $/ \mathrm{h} /$.

13 To patronimsko ime, nastalo od albanskog imena Pal (Palj)< Paulus ili Pavao, Pavle. Danas je u Arbanasima (istočno predgrađe grada Zadra) često prezime De Spal (i)>Dešpalj. Dešpalji su se, naime, bježeći u 17. stoljeću iz okolice Skadra 
U ovim rodovskim naseljima, gdje su žitelji istog prezimena, a mnogi nose i isto osobno ime, stanovnici se međusobno prepoznaju po osobnom ili obiteljskom nadimku.

Nekoliko zaselaka Krivoga Puta ${ }^{15}$ nose imena po obiteljskim nadimcima matične prazadruge, kao npr. Milčići (Krmpotići-Milčići), Rusova Draga (Prpići-Rusovi), Sovića Draga (Tomljanovići-Sovini), Popići (Prpići-Popići), Tusi (Pavelići-Tus), Markuzi (Pavelići-Markuzi), Tamburi (Prpić-Tamburi), Škopci (Krmpotići-Škobac), Lopci (Prpići-Lopci) Zečevi (Krmpotić-Zečevi), Grujičin Dolac (Tomljanovići-Grujice). ${ }^{16}$

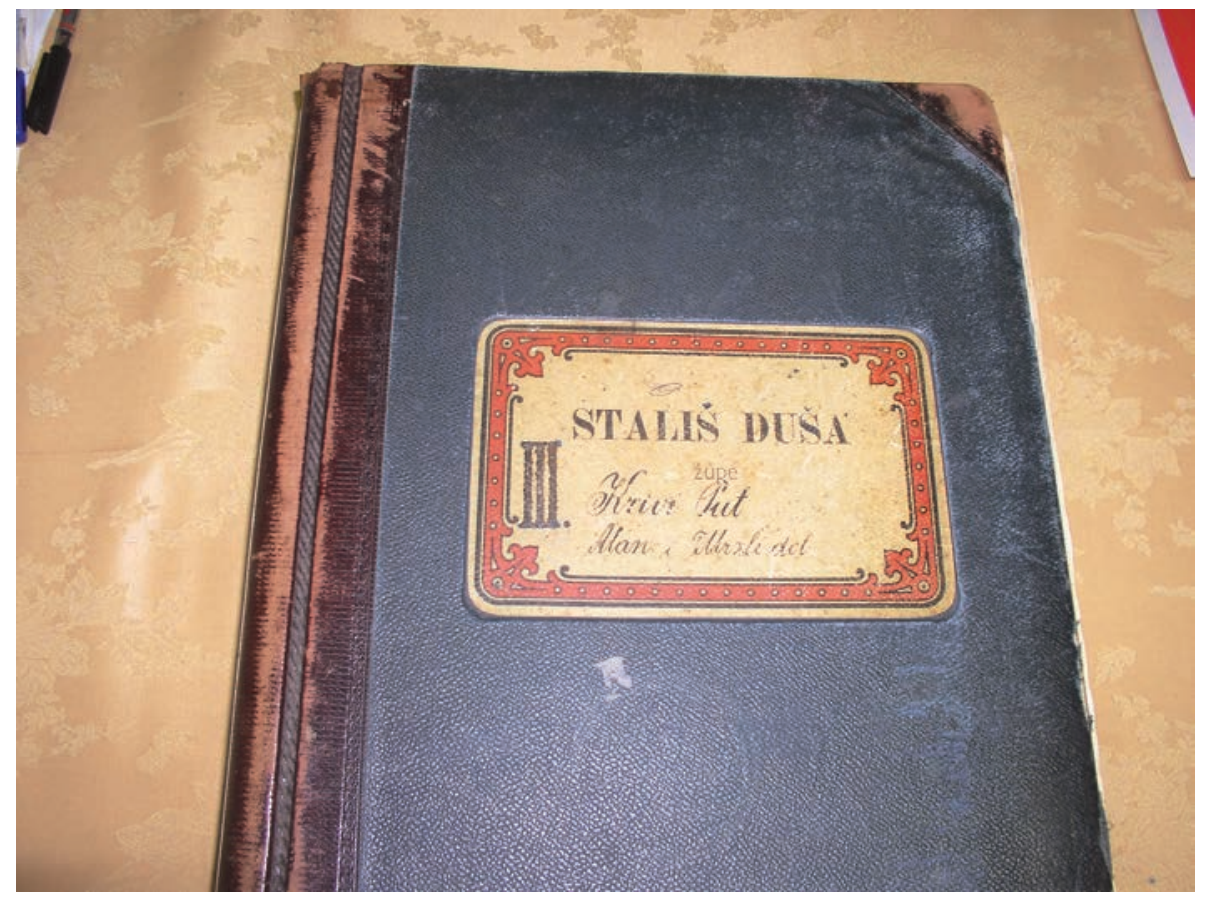

Slika 1: Stališ duša (Status animarum) Župe Krivi Put, knjiga III.; snimila Blaženka Ljubović, Gradski muzeja Senj, veljača 2009.

\subsection{MUŠKA OSOBNA IMENA}

$\mathrm{N}$

ajčešće zastupljena muška osobna imena stanovnika Krivoga Puta $\mathrm{su}^{17}$ : Andrija> Jandre, Jandran, Antun>Ante, Anton, Avram, Blaž, Božidar>Božo, Branimir>Branko, Dujo, Mišo, Mirko, Miko, Mime, Damjan> Dane, Domagoj, Dominik, Filip, Davor, Dragutin>Drago i Dragan, Karlo, Franjo>Frane (Vrane), Nina, Gabrijel>Gabro, Gojko, Grgur>Grga i Grgo Ivan>Ive, Ivo, Ivica, Ilija i Ico, Ilija, Izidor, Jakov, Jerko, Josip>Joso i Josica, Juraj>Jure, Juka i Jurica, Krunoslav>Krune, Krešimir>Krešo, Kuzman>Kuzma, Lovro $>$ Lovran,Lovre, Luka>Lukina, Marijan>Marin i Marinko, Martin>Maco, Milan>Mile, Mićo, Mijan,

u Albaniji, naselili u Arbanasima na mletačkom teritoriju. Prezime je etničkog podrijetla nastalo po imenu naseobinskog kraja na sjeveru Skadarskog jezera”. (Šimunović 2006: 319 -320).

14 O naseljima i zaselcima Krivoga Puta opširnije u: Korenčić 1979: 603-609, Feldbauer 204:I., 7., I., 384, II., 503 II., 593-594, II., 843 i II., 867 i Ljubović 2008: 52-54.

15 Franjo Julije Fras u: Topografija Karlovačke Vojne krajine 1835:192, navodi: Krivi Put je kapetanska postaja i selo s 98 kuća, 1246 katoličkih žitelja, s katoličkom župnom crkvom te postajom tridesetničara u sastavu Ogulinske graničarske pukounije.

16 Do ovoga zaključka došao sam razgovarajući s mnogim Krivopućanima, budući da o prezimenima i nadimcima Krivoga Puta nema do sada objavljenih radova.

17 Više o osobnim imenima u Hrvata u: Šimundić 1988:1-571. Do ovoga zaključka došao sam detaljnim pregledom knjiga Stališ duša (Status Animarum), Župe Krivi Put, knjige I, kućni broj od 3 do 371, knjiga II. kućni broj 371 i dalje i knjiga III; Alan i Mrzli Dol. Zahvaljujem se senjskom župniku i kanoniku Senjskog kaptola prečasnom gospodinu Mili Cančaru, koji mi je ustupio na pregled knjigu Stališ duša Župe Krivi Put. 
Mijo i Mijat, Mladen, Nikola>Niko i Nina, Mihovil>Mićo, Mile, Miljenko, Milovan, Miroslav>Miro, Mišo, Marko>Markan, Markica, Markutina, Mate, Mateša, i Milko, Pavle >Pave, Paval, Petar>Pere, Perica, Pece, Peko, Pile i Pešo, Rok>Roka, Vincencije>Vice, Vico, Vinko i Viki, Slavko>Slaven, Slave, Srećko, Stipan> Stipe, Stipurina i Pićo, Šimun, Tomislav>Tomo i Tone, Vale>Vališa, Vid>Vide, Vladimir>Vlado, Vlade, Vlatko, Zdravko, Zlatko i Žarko.

\section{3. ŽENSKA OSOBNA IMENA ${ }^{18}$}

Tajčešće zastupljena ženska osobna imena u Krivome Putu su ova:

Ana>Anka, Ankica, Antonija>Tonka, Blaženka>Blaža, Božena>Božica, Branka, Danica, Dragica $>$ Draga, Dunja, Francika $>$ Franjka, Franca (Vranca $)^{19}$, Đurdica $>$ Dura, Ivana, Ivanka, Jelena $>$ Jelka, Jela, Julija>Jula,Julka, Jadranka>Jada, Joka, Klara, Lenka, Luca>Lucija, Josipa, Katarina>Kata, Katica, Kaja, Karma, Ljerka, Ljuba>Ljubica, Manda>Mandica, Marija>Marica, Mara, Marina, Marijana, Marinka, Marijanka, Marta, Martina, Maša, Maca, Milica>Milka, Mica, Miljenka, Miroslava>Mirjana, Mira, Mladena, Ruža>Ružica, Slavka>Slavica, Slava, Štefa>Štefica, Štefanija, Tomislava, Tereza, Vera, Zdenka i Zorka $>$ Zora, Zorica.

\section{OBITELJSKI NADIMCI, OSOBNI MUŠKI I ŽENSKI NADIMCI}

U Tmnogobrojnim krivoputskim rodovskim naseljima, svaka je obitelj imala, a najčešće ima i danas, nadimak-priimak ili špicnamet (njemački: Spitzname ${ }^{20}$ ), kako stanovništvo često naziva obiteljski nadimak koji se uglavnom nasljeđivao.

Obiteljski nadimak najčešće je izveden od osobnog nadimka kojeg je nositelj stekao na različite načine, npr. Gara (osoba crne puti), Kišs, ${ }^{21}$ Brkac (čovjek koji ima brk), Vickov ${ }^{22}$ (potomak Vicka), Šnajdar ${ }^{23}$, Birt, ${ }^{24}$ Samardžija ${ }^{25}$ itd.

Često nadimci ovoga kraja izražavaju duhovna, karakterna i tjelesna obilježja osoba u pojedinim obiteljima, a različiti opsceni nadimci ne doživljavaju se u ovoj sredini kao opsceni, npr. genitalije, koje kroz dugu povijest još od paleolitika simboliziraju plodnost, npr. Kure, Kurčin, a iz razgovora s nositeljima ovakvih nadimaka nisam primijetio da se srame, nego su čak i ponosni na svoje nadimke jer simboliziraju muškost i seksualnost. ${ }^{26}$ Nadimci ovoga kraja, uz jezičnu obavijest koju nose, često odražavaju socijalne

18 Stališ duše, Župe Krivi Put (Status animarum), knjiga I, kućni broj 3 do 371, knjiga II, kućni broj 371. i dalje i knjiga III, Alan i Mrzli Dol.

19 U krivoputskom štokavskom govoru glas $\mathbf{f}$ izgovara se $\mathbf{v}$, pa otuda imamo i izgovor osobnih imena Vrane (Frane), Vranca (Franca) te izgovor naziva toponima-zaselaka Vrancikovac (Francikovac) i Vrataruša (Frataruša). Fratri samostana sv. Jelena imali su preko brda svoje posjede, na što upućuje naziv Vrataruša. Više o crkvenim redovima na području Krivoga Puta u radovima gospićko-senjskog biskupa msgr.dr. Mile Bogovića u: Senjskim zbornicima 15(1988), 109-120 i 17(1990), 69-92. Opširnije u: Bogović 2008: 69.

Senjski franjevci (franciscani ) imali su posjede iznad Senja, otuda naziv Francikovac. Neki smatraju da je u Francikovcu u srednjem vijeku bila opatija sv. Dujma. Opširnije u: Bogović 2008: 69.

Njemački, Spitzname(n) der,-(n)s,-(n), nadimak. Vidi opširnije u: Hurm 1959; 631.

21 Kiš od: kišur, -ura, mađ.( kis-malen, ur -gospodin) ili mladić iz ugledne obitelji mladi gospodin. Klaić 1988: 692.

22 Ovaj nadimak kao i većina nadimaka izvedeni su od osobnog imena nekoga od predaka (oca, djeda, pradjeda) koji je bio rodonačelnik tj. starješina obitelji. Obiteljski nadimci se prenose na potomke, sinove i kćeri, kao npr. Jolini, Jukšini, Miškecovi, Milčici, Milajsini, Miškovi, Miladiinovi, Markišini i drugi.

23 Šnajder, 2. mn. šnajdera, njem. Schneider-krojač. Opširnije u: Klaić 1988: 1300.

24 Birt, njem. Wirt 1. birtaš-aša-gostioničar, krčmar. 2. katkada i umjesto birtija, bircauz, bircuz. Klaić 1988: 176.

25 Samar,ara, novogrčki (samarion), sedlo, tovar, Klaić 1988:1191. Onaj koji izrađuje samare zove se samardžija, a postoji i bunjevačko prezime Samaržija iz okolice Senja (Stolac, Oltari).

26 Više vidi u: Salopek 2007:229.-235.) 
odnose u raznim dobnim, prostornim, staleškim i profesionalnim sredinama. Takvi nadimci su: Ban, Kralj, Car, Cestar, Knez, Šnajdar, Blagajnik, Lugar i Apel ${ }^{27}$ jer su zauzimali posebno statusno mjesto u seoskoj društvenoj hijerarhiji, a njihovi obiteljski nadimci pokazuju također važnost i značaj tih obitelji u maloj sredini.

Nadimci se, radi lakšeg identificiranja, navode i na nadgrobnim spomenicima, tako u krivoputskom groblju u Podbilu većina osoba ima isklesan obiteljski nadimak (sl. 2)

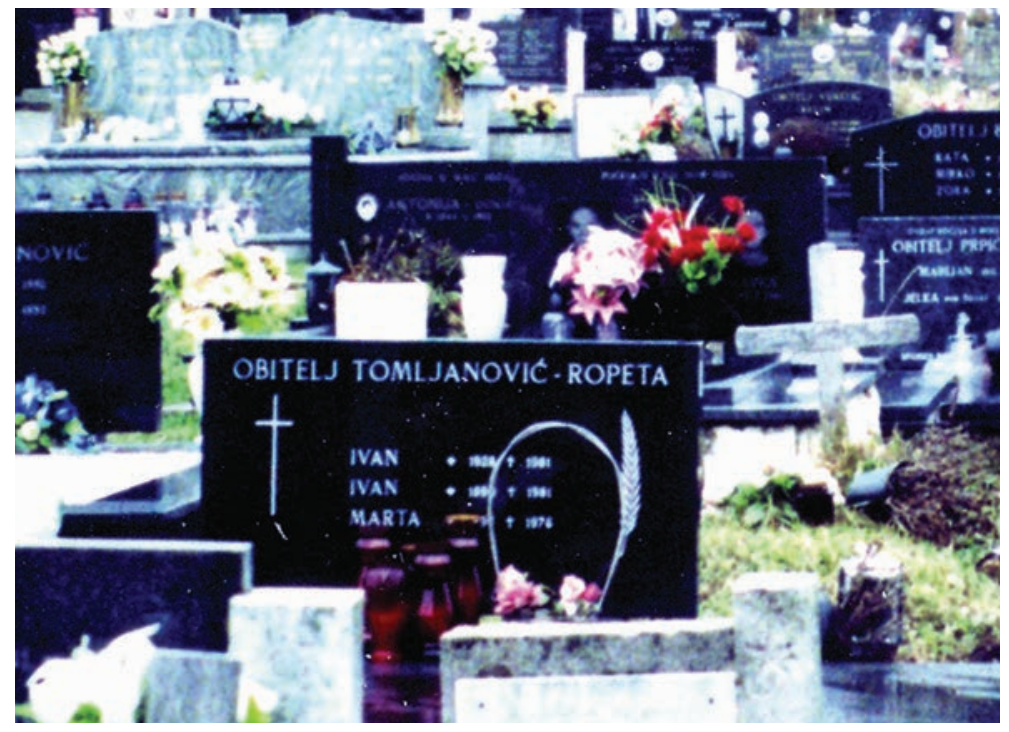

Slika 2: Groblje u Podbilu, iz Fotoarbive Gradskog muzeja Senj.

\subsection{POPIS OBITELJSKIH NADIMAKA PO PREZIMENIMA I NASELJIMA}

Tovom odlomku navodim obiteljske nadimke koji danas postoje i koji se koriste u svakodnevnom razgovoru, jer su se mnogi nadimci vremenom izgubili, tj. zaboravili. Nadimke ću povezati s prezimenima i svrstati ih pod mjesta krivoputskog područja. ${ }^{28}$

\section{1. 1.NASELJE ÀLAN}

U naselje Alan spadaju zaseoci: Rupa, Vukelići-Brina, Butković Dolac, Cîgići, Klânac Àlanski, Vrtlina i Zamâlić ${ }^{29}$

TOMLJĀNOVIĆ, Zamâlić

Ámpulica, Blàžić, Carevi (i Máksini), Kaja, Mićan, Pèriša (Mića) Pùpan, Prôtov, Talijan, Samárdžija, Tàmbur

27 Tomo Špalj Cucin, iz Gornjih Špalja objasnio je nastanak nadimka Apel: Jedan iz člana obitelji Prpić iz Matića bio je poljar za vrijeme Austrije, te je stalno govorio, apelirao da se čuva stoka i da se ne pušta slobodno na njive i livade, pa je zbog stalnog apeliranja dobio nadimak Apel.

28 Posebnu zahvalu dugujem kazivačima: Ani Krmpotić Bojinoj, Brdinoj, Đurđici Lopac Vickovoj, Branku Tomljanoviću Ropeti, Tomi Špalju Cucinom, Milanu Krmpotiću Tralji, Mladenu Prpiću Bojinom, Bradi, Mladenu Šojatu Bilinom, Milanu Šojatu Colašu, Mirku Krmpotiću Tabanu, dr. Željku Tomljanoviću Nožici, Marku Vukeliću Mrci te Marijanu Paveliću Mašinom iz Pavića koji su mi nesebično pomogli u sastavljanju popisa obiteljskih nadimaka, razvrstanih po prezimenima i naseljima krivoputskog kraja.

Sve nadimke je akcentirao književnik Milan Krmpotić, rođenjem Krivopućanin, a danas živi i radi u Senju.

29 O naseljima i broju stanovnika Krivoga Puta od 1857. do 1971. Opširnije u: Korenčić 1979: 603-609, Feldbauer 2002: I., 7 i Ljubović 2008:52-54. 
VUKELIĆ, Rupa

Anta, Bager, Bartol, Deviza, Gûšin, Grašin, Grgičin (i:Lujin), Juričin, Kožûnov Kúrčina, Lugar, Mácin, Pòpov, Rokić, Šeprndin, Tomičin, Torešin

VUKELIĆ, Vukelići-Brina

Antonéčv (i Antonéca), Bêle, Cija, Drvenica, Gúžve, İvelica, Kùjan, Krkin Lukac, Mutin, Mrce, Mrkin (i Mrkeša), Risov, Šigo, Škéra, Šlik, Tînac, Vole

FILIPOVIĆ, Vukelići

Vàliša

BUTKOVIĆ, Alan

Gara, Jòlina, Krunin, Nónić, Ruskinjin (i Blāževi)

TOMLJĀNOVIĆ, Alan

Marić, Mrda

TOMLJĀNOVIĆ, Cìgići

Cúle, Dujan, Kule, Pilić, Vîde

BUTKOVIĆ, Vrtlina

Rila, Čadeša, Čuža (i Bòskovi), Marijànić

TOMLJĀNOVIĆ, Vrtlina

Ântin, Batina, Bura, Čadeša, Jùrina (i Mîlka), Kòmar, Marjanić i Omanić

BUTKOVIĆ, Butković Dolac

Bùsáa, Subota, Tôpo

PRPIĆ, Butković Dolac

Brkac, Perica

TOMLJĀNOVIĆ, Butković Dolac

Bègan, Gude, Kuić, Skâle i Vôrgo

\section{1. 2. NASELJE PÒDBILO}

U naselje Podbilo spadaju zaseoci: Cupići, Matići, Murtići, Panjići, Plemići, Podbilo (mjesto), Šimerići, Šolići, Tomići i Žuljevići (Korenčić 1979:603-609, Feldbauer 2004:593-594 i Ljubović 2008:52-54).

TOMLJĀNOVIĆ, Cûpići

Bâra, Cija, Č̂̀na, İvići, Jóle, Roša

TOMLJĀNOVIĆ, Panjići

Bareta, Bâjo, Bürlina, Caljina (i Gićān), Dada, Dokonja, Drimalica, Gilja, Grgúr, Jukša, Ikêla, Kikeš, Lasica, Markêž, Mica, Mijàtina (i Zêkicí, Grobar) ${ }^{30}$, Nîkić, Prgấč, Pugân, Puljîz, Ružin, Solkan, Šimàica, Škoro, Šuškalo, Tôjo, Tôle, Vugêrija.

30 U zaselku Zekići(Podbilo) živi obitelj Marka Pavelića Zekić, Mijatina, Grobar koja se doselila iz zaselka Bile u naselju Krmpote, a Marko Pavelić najstariji je stanovnik Krivoga Puta iz muške populacije. 
TOMLJĀNOVIĆ, Šìmērići

Adam, Bareta, Côto (i Svéćev i Burlina), Crvēnko, Čicrma, Gecan, İvela, Kesa, Màreta.

TOMLJĀNOVIĆ, Murtići

Bân

TOMLJĀNOVIĆ, Tōmići

Bájo, Bulina, Drímalica, Jérko, Jakša, Mâcak, Màrkiša (i Kanada), Rámbula, Pî́o (i Matela), Škōro, Toniša, Àmpulica

TOMLJANOVIĆ, Matići

Jukša, Pî́co (i Matela), Miliša-Zekan

TOMLJĀNOVIĆ, Žûljevići

Màrkeša, Tòniša, Vrân

TOMLJĀNOVIĆ, Plemići

Bukva, Juko, Kečina, Klica, Matan, Mukin, Papaga, Perîć Perić, Pržina, Rebica, Rîža

PRPIĆ, Matići

Àpel, Bâre, Fuks, Íso, Leca, Màrkac, Markin, Miloš, Mukin, Pêce, Šêko, Šìmac, Šoparîn, Télac, Tóle i Vickov (i Ilijin, Mâsin) i Zécevi.

TOMLJĀNOVIĆ, Plovànija

Krnota, Bele i Oporavija

PRPIĆ, Pòdbilo

Mrda (i Júrčić)

PRPIĆ, Plemići

Čubrk i Peričin

ŠŌLIĆ, Šōlići

Batàlija, Čâmbre (i Batàlija), Ljíbina, Pùrica, Mícel, Murta, Tutan, Josùtina

TOMLJĀNOVIĆ, Šōlići

Murta

VUKELIĆ, Cûpići

Mikula

\section{1. 3. NASELJE KRIVI PUT}

U naselje Krivi Put spadaju zaseoci: Krivi Put, Gorica Judića ili Krivoputska, Longovac, Lukići, Nikolići, Šašina, Šojatski Dolac, Gornji Špalji, Špinići i Zekanovići (Korenčić 1979:603-609, Feldbauer 2004. I.: 384 i Ljubović 2007: 52-54)

PRPIĆ, Krivi Put

Baja (Mikelin), Bàriša (Màgarac), Blagajnik, Búre, Čikan Junac, Ìvanov (i Židār) Jāgić, Krazma, Kujica, Jukin, Kòvač, Àntišin, Mîlić, Āntin, Buva, Cungo, Bàbica, İvanov, Jukin, Kupus, Keba, Bokan (i Bôži- 
ni), Tèrēzin (i:Mutin), Poštar (i:Miš), Duda, Baja (i:Kapulica), Stipina, Šuvôr, Îcin, İvanov, Rùsān, Pèsar, Ùdulin, i Zidàr

PRPIĆ, Lukići

Àntiša, Bàriša, Butîga, Gàjtan, Tkâljac, Č̂̀ro, Čuk, Jâgić, Cija, Jerkov, Junac, Kujica, Lucin, Lukičin,

TOMLJĀNOVIĆ, Krivi Put

Gâla, Ròpeta

ŠPĀLJ, Krivi Put

Màcáan (i Pèntić)

PRPIĆ, Judića Gorica

Dalmatīnac, Dòmljan, Jòžina, Juda Martâva, Miškec

PRPIĆ, Longovac

Àbram, Baja, Kènig, Nîkin, Paja

PRPIĆ, Nikolići

Juda, Keza, Màtela, Màrkêż (i: Mican), Matković, Mrda, Milâjsa (i Bân), Mùnela, Štelîna, Vranela

PRPIĆ, Šašina

Bus, Gusle i Matkov

ŠÒJAT, Šòjatski Dòlac

Bâbić (i:Šôrda), Budíc, Balūn, Brk, Braić (i:Paljak), Čemôrac, Dràjsan, Gôlija, Grabarovi, Lòjza, Lovran, Lùda, Marić, Môko, Provôz, Skula, Škôbac, Vâle, Vran, Vice.

PRPIĆ, Š̀jjatski Dòlac

Jàndran, Šuljac

KRMPOTIĆ, Šojatski Dolac

Šoparîn

ŠPALJ, Gornji Špálji

Dúkan (i Pop), Jêž, Mâtin (i Dujičin)

PRPIĆ, Gornji Špálji

Mizérija

PRPIĆ, Špinići

Bódul, Lùkinovi, Pèrina, Špirin, Tomina Vrànčina

ŠPALJ, Zèkanovići

Cucin, Kebîn, Kljápo

TOMLJĀNOVIĆ, Zèkanovići

Cucin, Dujičin, Gala, Lôvre, Lóko, Màrela, Ròjilo, Sôso i Žilica 
PRPIĆ, Zekanovići

Mìzērija

Tijekom ljetnih mjeseci u Zekanoviće su selili, iz Donjih Špalja, obitelji: Antonovi, Bêle, Grgušs, Vrànela, Zvîrac. $^{31}$

\section{1. 4. NASELJE MRZLI DOL}

U naselje Mrzli Dol spadaju zaseoci: Iličići, Katići, Kostići, Lipa Jela, Lucići, Miškovica, Pavelići, Pavići, Popići, Rusova Draga, Stanić Brig, Tamburi, Tusi i Markuzi (Korenčić 1979: 603-609 i Felbauer II., 503)

TOMLJANOVIĆ, Katići

Bojini, Cî̀ro, Rîlac, Puž, Miládina, Maričin, Cîrin, Lôkin, Kôcina

PRPIĆ, Katići

Sùlinovi

PAVELIĆ, Lipa Jela

Miškov, Nona

PRPIĆ, Lucići

Antelîca, Anikin, Mïjin, Lega, Lôko, Katić, Kavàrica, Màtoš (i Dânin), Marojica, Pićina, Tomas. Vî̀ce, Švorac, Vuk i İviša

PRPIĆ, Kostići

Čiko, Kosta

PAVELIĆ, Pavelići (Pòdgaj)

Šćâva, Vaja (i Bêle), Mîcin, Gužva, Perijān, Círilov, Kâtić, Kùzman, Dânin, Mârtin

PAVELIĆ, Pāvići

Bùrgija (i: Medonja), Josin, Mèdonja (i Mateša), Mâšin (i Jurin), Matin, Mijān, Sikirica (i Vranjin), Tòmiša, Tomin, Vrànjić

PRPIĆ, Popići

Pòpić, Zòzan

MIHĒLAC, Popî́i

Mêlac

PRPIĆ, Rusova Draga

Rus, Gobac, Sŕna, Bačve, Birt

PRPIĆ, Stànić Brīg

Bâčve, Jòsina, Jùrina, Pàviša,

31 Po pričanju kazivača Tome Špalja Cucina iz Gornjih Špalja. 
BLĀŽEVIĆ, Stànić Brīg

Kàjela, Kênig, Sìrac, Jôjo, İvela, Nikolin, Šarac, Trècak, Šnâjder

PRPIĆ, Tàmburi

Tàmbur

PRPIĆ, Miškovica

Môro (i Šnàjdar)

PAVELIĆ, Tusi i Markuzi

Tus, Markuz ${ }^{32}$, Jérkov, Ugljevar, Zozan

\section{1. 5. NASELJE VRATARUŠA}

U naselje Vratarušu spadaju zaseoci: Bunica, Vrataruša (mjesto), Gujičin Dolac,Sveta Jelena, Klaričevac, Klenova Kosa, Murva, Pijavica, Sibinj Krmpotski, Sovića Draga, Kosova Buljima, Kriva Draga, Šušanj Krivoputski, Tanka Buljima, Vodna ( Korenčić 1979: 603-609., Feldbauer II. 2004: 867 i Ljubović 2008: $52-54)$

TOMLJĀNOVIĆ, Bùnica

Bàtina, Komar, Lukša, Miš, Mòtika, Šāre

ŠPALJ, Donji Špalji (Sveta Jelena)

Béle, Mākulica, Púze, Šàrac, Škica, Škrālje, Vràneta, Zvirac

PRPIĆ, Pījavica

Čàvlina, Gudalo, Gute, Lukin. Mukin, Ralić, Vránce

PRPIĆ, Klāričevac

Cōto, Dēde, Gíguš, Milok, Mojzel, Pive, Púca, Š̀jina, Škrālje, Štanjár, Vrljan, Žilica.

TOMLJĀNOVIĆ, Vratàruša

Dujās, Guslić, Kàrtač, Grgàica, Komàrica, Livak, Màčan, Mòtika, Nožica, Pácula, Pušililo, Psever, Roka.

PRPIĆ, Kôsova Buljma

Grgàjica, Kos, Špîro

PRPIĆ, Šušanj

Brkac (i Pếsini)

TOMLJĀNOVIĆ, Šušanj

Gude i Käić

TOMLJĀNOVIĆ, Cupina - Sibinj Krmpotski

Àmpulica, Bikan, Began, Car (i Máksini), Cestar, Dada, Kîle, Jole, Léso, Joja, Sovo, Sópeta, Tojo, Tàmbur, Vügerija

32 Šimunović 2006: 326. Nadimak Markus ili Mark(uz) nastao je od latinskog imena Marcus (od Mars-rtis), tako da se ovo ime vremenom širilo imenom apostola i sveca Marka, koji je bio i nebeski zaštitnik Venecije. 
TOMLJĀNOVIĆ, Vodna

Lisica i Kotur

TOMLJĀNOVIĆ, Klenova Kosa

Dada (i:Dadić), Joja

PRPIĆ, Òsredak

Gùsina, Kure

BUTKOVIĆ, Sibinj Krmpotski

Blaž, Blažina, Cole, Milin, Roka, Stipan, Tòmin

\section{1. 6. VÈLJUN PRÎMORSKI}

Pod naselje Veljun Primorski spadaju zaseoci: Brizica, Burići, Brizica, Veljun (Gornji i Donji), Fráncikovac, Grujići, Kuljići, Lopci, Lukci, Marīnovići, Milčići, Mlići, Petuova, Rončevići, Suzna Dolina, Šabani, Škobci, Tabani i Zečevi (Korenčić 1979: 603-609 i Feldbauer, II. 2004: 843).

PAVELIĆ, Serdāri (Srdari)

Jandra, Dùjela, Pòbedrica, Krè̌imirovi, Pset

PRPIĆ, Serdāri (Srdāri)

Jüda (i Böjin), Duda

RÒNČEVIĆ, Rōnčevići

Bivina, Jola, Nikolini

KRMPOTIĆ, Suzna Dòlina

Dujica, Kàvar, Isān, Jùcan, Màzija, Milina. Š̀̆go, Šimèta, Šában, Vinin, Vúčina, Zêe, Zékonja

KRMPOTIĆ; Dônji Vèljun

Grabār, Pera, Peša, Švábo, Zềc, Žîle

KRMPOTIĆ, Gôrnji Vèljun

Gvera, Kavār (i Josèla), Karlov (i Putlja), Ivešin, Janjin, Lïle, Rus,

Vìdin (i Šimunov)

KRMPOTIĆ, Tàbani

Tàban

KRMPOTIĆ, Brizica

Bernde, Ivēta, Pênte, Švabo

KRMPOTIĆ, Kûljići

Bokulić, Pičica, Putlja, Ždrôko

PRPIĆ, Kûljići

Markin 
KRMPOTIĆ, Lukci

Lukac, Milinovi, Miš̌̃na, Radin, Zêc

KRMPOTIĆ, Marīnovići

Ànelica, Lêjo, Migec, Mìlčić, Pàvan, Perinkin

KRMPOTIĆ, Mīlčići

Mīlčić

KRMPOTIĆ, Mlī̌i

Kljapan, Marelica, Mlič, Prdalj, Sokol

KRMPOTIĆ, Škôbci

Antèlija, Econja, Kásela, Tralje, Škôbac, Šoparīn

KRMPOTIĆ, Zêčevi

Zêc

LOPAC, Zečevi

Šenac (Frane Lopac)

ŠÒJAT, Šàbani

Šàban

KRMPOTIĆ, Petuova

Trtan

PRPIĆ, Fráncikovac (Vrancikovac)

Copić, Kurte, Lopac, Markičin, Savić, Sōko

ŠÒJAT, Fráncikovac (Vrancikovac)

Bàraba, Bïle, Bójić, Còlaš, Juričin, Kesa, Kìkić, Klāra, Lugárov, Márkišin, Milānko, Ninac, Pàvić, Pešóta.

TOMLJĀNOVIĆ; Fráncikovac (Vrancikovac)

Gulaš

\subsection{OSOBNI MUŠKI NADIMCI}

$\mathrm{O}$ sobni nadimci su uglavnom nastali prema prepoznatljivim fizičkim i karakternim oznakama neke osobe, odnosno prepoznatljivim duhovnim i tjelesnim osobinama. Nadimci tako predstavljaju specifično obilježje relativno male i zatvorene sredine koju karakterizira međusobna ovisnost žitelja te upućenost jednih na druge.

U ovakvim sredinama česte su i rodbinske veze, pa zbog toga jedna obitelj ima više od jednog nadimka, zbog toga što su se gotovo svi nadimci kroz nekoliko generacija zadržavali. Osobni nadimci uglavnom prelaze u obiteljske u drugoj ili trećoj generaciji.

Neki osobni i obiteljski nadimci Krivopućana u nekim drugim krajevima Hrvatske imaju funkciju prezimena, kao npr. Čuk, Lopac, Gecan, Fuks, Šnajder, Birt, Čamber, Marelica, Anelica itd. 
Tako npr. više nadimaka ima obitelj Pavelić Marka Zekić, Mijatina, Grobar iz Podbila, obitelj Prpić iz Serdara Bojini, Juda, Prpić iz Matića s nadimcima Mašin, Ilijin i Vickov, Tomljanović iz Alana s nadimcima Carevi i Maksini, Pavelić iz Pavića s nadimcima Burgija i Medonja, obitelj Tomljanović iz Šimerića s nadimcima Coto, Svećev i Burlina itd. ${ }^{33}$

Nekoliko osobnih muških nadimaka iz Krivoga Puta:

Aladar, Bartol, Bika, Bikac, Bili, Blitva, Buba, Brk, Bukva, Bunjo, Brada, Bure, Ciko, Cigo, Crvenko, Cvija, Čaruga, Čoban, Čopo, Čoro, Coto, Cole, Čotol, Čuk, Ćubina, Dalmatinac, Fabo, Fuks, Gara, Gumeša, Guza, Gušte, Indus, Jale, Jukan, Kanada, Keba, Kusa, Krazma, Lasa, Lele, Lugarov, Major, Maleta, Marela, Meduza, Mičel, Mićina, Mijatina, Miki, Milanić, Marenda, Mizerija, Muša, Padelica, Pile, Paljak, Pivalica, Rus, Ruskinja, Samac, Mata, Stipina, Stipurina, Svileni, Špika, Šumar, Talijan, Tava, Turina, Tarigora,Udulin, Vranac, Vrangel, Vugerija, Žutija.

\section{3. ŽENSKI OSOBNI NADIMCI}

\section{$\check{Z}$} ene su se najčešće identificirale osobnim imenom, a ako to nije bilo dovoljno, uz ženino ime dodavalo se ime ili prezime oca ili muža. Žene su tek od Tridentskog koncila (1545.-1560.) dobivale prezime po očevu koljenu djevojačko, a udajom dobivaju muževljevo prezime (usp. Šimunović 2006: 42). Često se prezimenom i nadimkom u manjim sredinama isticala posvojnost, a time i ovisnost i to uglavnom u seoskim sredinama kao što je bilo područje Krivoga Puta.

Žene u Krivome Putu najčešće dobivaju nadimak djevojačkog roda (oca), a kada se udaju dobivaju mužev obiteljski nadimak, npr. Jola-Jolina, Kavarica-Kavaričina, Vicko-Vickova, Čambre-Čambrina, Čona-Čonina, Balun-Balunova, Jukša-Jukšina, Periša-Perišina, Šimaica-Šimaičina itd. Neke žene su i udajom zadržale svoj djevojački nadimak i po tome se identificiraju, kao npr. Mara Tomljanović Isanova, koja je iz obitelji Krmpotić Isan iz Veljuna Primorskog ili Nada Prpić Bojina, udala se za Prpića Terezinog, ali i dalje koristi svoj djevojački nadimak. No od pojedinih žena nadimak se prenosio na čitavu obitelj i to u situacijama kada su se u lokalnoj zajednici isticale po nečemu. Takvi nadimci od osobnih postajali su također obiteljski, kao npr. Boja, Terezini, Puca, Kajela i Milišina.

Ponekad je čitava obitelj dobivala nadimak po ženi i to najčešće kada su žene bile nositeljice zajedništva obitelji, odnosno muškarci iz tih obitelji su zbog posla izbivali iz kuće. Zbog rada u raznim krajevima Hrvatske i u europskim zemljama, muškarci su bili odsutni od kuće veći dio godine, a kod transkontinentalnih migracija i po nekoliko godina ${ }^{34}$. Snahe su u obitelji dakako ulazile udajom i dobivale dužnosti i obveze koje su ponajviše uključivale rađanje potomaka i odgoj djece, rad u kućanstvu, na zemljoradnji i brigu oko domaćih životinja, a o raspodijeli gospodarskih poslova u odsutnosti muškarca odlučivala je najstarija žena.

Dakako ovo nisu bili jedini razlozi usvajanja ženskih nadimaka, često se radilo o prepoznatljivoj ženskoj osobi koja je bila veoma utjecajna u lokalnoj zajednici i koja je obavljala neku važnu društvenu djelatnost. U obitelji Prpić u Krivome Putu bila je jedna babica (primalja) koja je porodila mnoge Krivopućane, a po kojoj danas svi njezini potomci nose nadimak Babica-Babičini, kazao je Vlade Prpić Babica.

Primjeri: Anika (Anka)-Aničn, Bara-Barin, Boja-Bojini, Bika-Bikini, Duda-Dudin, Isan-Isanova, Janja-Janjin,Klara-Klarini, Luca-Lucin, Lukica-Lukičin, Kaja-Kajini, Kajela-Kajelin, Maša-Mašin, Mica-Mi-

33 Jedan od Pavelića iz Bila (Krmpote) bio je priženjen u zaselak Zekići, pa je pored svog obiteljsko nadimka Mijatina dobio i novi Zekić, a treći nadimak Grobar je osobni jer je Marko grobar u Krivome Putu.

Drugi primjer su obitelj Prpića iz Serdara, koji su imali stari nadimak Juda iz Judića Gorice, a novi nadimak su dobili nakon što se jedan od Prpića priženio u obitelj Pavelić u Serdare, pa su po babi Božici (Boji) svi dobili nadimak Bojini, koji i danas nose, a stari nadimak Juda gotovo da je zaboravljen.

34 Detaljnije o ekonomskim migracijama vidi u prilogu Marijete Rajković, Pregled migracija Krivopućana u prvom svesku Monografije. 
cin, Maca-Macin, Milka-Milkin, Maša-Mašin, Marica-Maričin, Marelica-Mareličin, Puca-Pucin, Ruskinja-Ruskinjin, Ruža-Ružin, Tereza-Terezin i Vranca (Franca)-Vrančina.

Osim ovih primjera zanimljiv je i ženski nadimak Klara koji je nastao tijekom 19. st. u obitelji Šojat u Francikovcu. Baka Klara bila je utjecajna i dominantna osoba u obitelji i u cijelom selu, tako da je njezina obitelj bila prepoznatljiva i identificirala se po njoj. Ovaj nadimak i danas nose njezini potomci, primjerice unuk Ive Šojat Klara i njegova djeca ${ }^{35}$.

\section{PODJELA NADIMAKA PO KATEGORIJAMA}

$\mathrm{O}$ biteljski nadimci nastali su od osobnih nadimaka ili prema osobnim i prepoznatljivim fizičkim i duhovnim oznakama i značajkama te karakternim osobinama. Ovakvi nadimci često imaju podrugljiv prizvuk, ali nemaju uvijek u sebi nešto uvredljivo već se sama poruga nalazi u nekoj pričici ili dogodovštini koja nadimku daje posebno značenje u lokalnoj zajednici:

Ampulica, Bačva, Balun, Baraba, Batina, Batalija, Bele, Bile ${ }^{36}$,Bokulic, Brzina ${ }^{37}$, Bulina, Bura, Burgija, Brk, Brkac, Brnde, Burlina, Bus, Butiga, Car, Colas ${ }^{38}$, Čambre ${ }^{39}$, Čavlina, Cemorac, Colaš, Coto ${ }^{40}$, Cole, Crvenko, Čičma, Čopić, Čopo, Čočo, Čubrk, Čule, Čuža, Dokonja ${ }^{41}$, Drajsan, Drimalica, Drvenica, Gajtan,

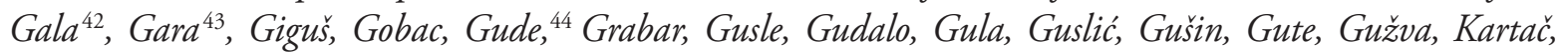
Kasela, Keba, Kečina, Kesa, Kile, Kiš, Kotur, Kožun, Kljapan, Krko, Kujan ${ }^{45}$, Kule, Kure, Kurčin, Livak, Loko, Luda, Ljibina ${ }^{46}$, Makulica, Mazija ${ }^{47}$, Migec, Mlić, Mrda, Mrkeša, Mrkin, Mizerija, Mrce ${ }^{48}$, Munela, Murta ${ }^{49}$, Motika, Mute, Nožica, Oporavija, Pacula, Paljak, Pentić, Peser, Pičica, Pivalica, Pive, Pržina, Pobedrica, Prdalj, Prgac, Psever, Pset, Pujica, Pupa, Puca, Puzle, Pušililo, Ralić, Sikirica, Sirac, Skale, Soko,

35 Mladen Šojat Bilin iz Francikovca i Milan Šojat Colaš iz Francikovca.

36 Nadimak Bile iz obitelji Šojat iz Francikovca nastao je još u 19. stoljeću. Naime, Mile Šojat, rođen 1870. i njegov unuk Mladen Šojat, rođen 1928., bavili su se zidanjem i paljenjem « japnenica» (vapnenica) te gašenjem japna (vapna). Kamen vapnenac paljenjem i gašenjem postaje bijele boje, pa je zbog toga i dobio nadimak Mile Šojat Bile. (Kazivači: Mladen Šojat Bile i Mladen Prpić, Boja, Brada).

37 Ovaj nadimak nose Tomljanovići iz Bunice. Naime, sin Ivana Tomljanovića, Mile Tomljanović (1912.-1985.) bio je hrom te se otežano kretao. Za očekivati je bilo da dobije nadimak Coto, Spori ili Tralje, ali njega su nazvali Brzina. (kazivač Mladen Prpić Boja, Brada).

38 Nadimak Colaš nastao je od glagola u hrvatskom jeziku colati, -am > tromo hodati ili šepati (Brodnjak 1992: 58).

39 Nadimak Čambre dolazi od turske riječi čam, čama > jela, smreka (Brodnjak 1992: 63).

40 Pridjev cotav, a, o znači > hrom, šepav (Brodnja 1992: 58.).

41 Nadimak je nastao u Alanu. U Alanu je živio čovjek koji je imao velikog konja, a bio je malen rastom. Kako bi lakše uzjahao konja, morao je tražiti neku uzvisinu. Budući da ne može «do konja», nazvan je Dokonja (kazivač Mladen Prpić Boja, Brada).

42 Gala, španj., svečano odjelo, svetkovina, blagdan, galantan muškarac, privlačan čovjek (Klaić 1988: 463).

43 Nadimak Gara nosi obitelj Butkovića iz Alana. Naime, članovi ove obitelji imali su tamnu kosu, bradu, obrve i brkove, pa su od riječi garav (taman, crn) dobili nadimak Garav, tj. po baki Gara (Mladen Prpić Boja, Brada).

44 Nadimak dolazi od hrvatskog glagola guditi, što znači lijepo i potiho pjevati.

45 Ovaj obiteljski nadimak Vukelića iz Alana nastao je od riječi kuja, kako se u krivoputskom kraju naziva kratki mali nož ili nožić.

46 Kazivač Branko Tomljanović Ropeta iz Krivoga Puta tvrdi da nadimak Ljibina znači, star, iznemogao i bolestan čovjek.

47 Nadimak Mazija u Arbanasima (istočno predgrađe Zadra) prezime je arbanaškog podrijetla, alb. mezi - čelik. Ovo ime je u toponimiju prodrlo vezano uz pučko sudstvo: Okrivljenik koji vadi užarenu maziju i pritom se ne opeče dokazuje svoju nedužnost. Opširnije u: Šimunović 2006: 139.

48 Nadimak obitelji Vukelića iz Alana, Mrce, dolazi od hrvatske riječi mrc, mrca m.>mrtvac (Brodnjak 1992: 291)

49 Nadimak Murta dolazi od riječi: murtat, m. i murtatin, tur.>izdajica, otpadnik od vjere(Brodnjak 1992: 294). 
Soso, Šarac, Šare ${ }^{50}$ Š enac, Šenprdin, Škera, Škica, Škoro, Škralje, Šigo, Šlik, Štanjar, Štelina ${ }^{51}$, Šuškalo, Šuvor, Švorac, Taban, Tambur ${ }^{52}$, Topo, Tralje, Trečak, Trtan, Tus, Tutan ${ }^{53}$,Vorgo, Vrljan, Vran, Ždroko, Zozan, Žile i ̌́ilica.

2. Nadimci nastali od osobnog imena česti su u mnogobrojnim obiteljiima krivoputskog područja, a pretežno su nastali od osobnog imena rodonačelnika obitelji:

Adam, Abram, Anelica, Antiša, Antonečev, Anikin, Antin. Abram, Baja, Bajo, Bara,Bareta, Babić, Bariša, Bartulov, Began, Blažićevi, Blažev, Blažina, Boškov, Božin, Boja ${ }^{54}$, Bralić, Budić, Cija, Čirilov, Danin, Dada, Domljan, Duda, Dukan, Dujan, Dujela, Dujica, Econja, Gecan, Grga, Grgajica, Ivetić, Ivić, Ilijin, Isan, Iso, Ivanov, Ivela, Ivelja, Iviša, Ikela, Isan, Jagić, Jandran, Janjin, Joja, Jola, Jandra, Josela, Jožina, Jukša, Juko, Jurin, Jolina, Joleta, Josetina, Jerkov, Josina, Jurčić, Kaić, Kajela, Kaja, Klara, Kosta, Krunin, Kuzman, Karlov, Krešimirov, Lejo, Lopac, Lovran, Lucin, Lukin, Lojze, Lucin Lukac, Lujin, Lukša ${ }^{55}$, Marela, Marić, Markina, Matela, Markež, Markac, Markan, Maksin, Marelica, Markina, Matkov, Marojica, Mateša, Matoš, Mašin, Matan, Mareta, Marić, Marijanić, Markus(z), Melac, Miladina, Mičel, Mičan, Mijatina, Mikula, Miloš, Mićan, Milić, Mikelić, Miškec, Mijan, Miškov, Miliša, Mican, Milojsa, Milina, Milčić, Mišin, Milanko, Moko, Mukin, Nikić, Ninac, Paja, Pavan, Paviša, Pece, Pešo, Peričin, Perijan, Periša, Pićo, Radin, Roka, Rokić,Roša, Ružin, Savić, Stipan, Stipin, Šaban ${ }^{56}$, Šimac, Špirin, Terezin, Tomas, Tomiša, Tomina, Tomin, Tinac, Vaja, Vališa, Vickov, Vide, Vinin, Vranela, Vranjić, Vrance i Vrane.

3. Obiteljske nadimke nastale od zanimanja, zvanja nositelja ili rodonačelnika rodovske zajednice nose neke obiteljske zajednice Krivoga Puta, a sličnih obilježja su i prezimena nastala od zanimanja rodonačelnika obitelji:

Apel, Babica, Ban, Blagajnik, Birt, Car, Cestar, Čoban, Grobar, Knez, Kovač, Kralj, Lugar, Pop, Popić, Poštar, Protov ${ }^{57}$, Nona, Nonić, Samardžija, Šnajder, Šoparin ${ }^{58}$, Tkaljac, Ugljevar i Zidar

4. Česti su i nadimci prema mjestu stanovanja, zavičajnoj pripadnosti i rođenju ili nadimci po lokalitetu (selu, zaselku otkud su došli ili gdje su nekad živjeli i radili), a mnogi nadimci po zanimanju i lo-

50 Nadimak Šare vezan je za obitelj Tomljanović iz Bunice. U Bunici je živio Ivan Tomljanović (1887.-1953.), bavio se zidanjem kao priučeni majstor zidar. Kako u to vrijeme nije bilo nacrta, on je po zemlji crtao, tj. šarao, pri tom su nastajale šare (skice), pa je zbog toga dobio nadimak Šare. Nadimak je prešao na sina Juru, a preuzeo ga je i unuk Vlade i praunuk Vlade mlađi, rođen 1976. (kazivač Mladen Prpić Boja, Brada).

Kćer Ive Tomljanovića Šare tvrdi da je otac imao na licu ožiljke od preboljelih kozica, pa je zbog toga nazvan Šare (kazivač Anka Tomljanović Šare, rođ. 1921., živi u Bunici).

51 Štelina je dio konjske zaprege, a ova obitelj se bavila prijevozom.

52 Nadimak Tambur je nastao od francuske riječi tambur m. > bubanj, zaklon na vratima za zaštitu od vjetra, kiše i snijega (Brodnjak 1992: 531).

53 Nadimak Tutan nastao od riječi tutenj m.> nespretnjaković (Brodnjak 1992: 540).

54 Nadimak Boja nose Prpići iz Serdara, a nadimak je nastao dvadesetih godina prošlog stoljeća. Unuk Jure naziva svoju baku Božicu, Boja, pa se ovaj ženski nadimak prihvatio, pa npr. (Mile Boja, Ive Boja, Kruno Boja itd.). Stariji nadimak ove obitelji je Juda iz Judića Gorice, a jedan od Prpića iz Judića Gorice priženio se u obitelj Pavelić u Serdare (kazivač Mladen Prpić Boja, Brada).

55 Ovaj nadimak nosi danas obitelj Tomljanović iz Bunice, a nadimak potječe iz 18. stoljeća, s područja sela Vrataruše, otkuda su podrijetlom Tomljanovići iz Bunice. Obiteljski nadimak izveden je od osobnog imena Luka (kazivač Mladen Prpić Boja, Brada).

56 Ovdje je osobno muslimansko ime Šaban u funkciji nadimka. Riječ je turskog podrijetla (Saban), arapski (Šaban). Naime, tako se zove osmi mjesec lunarne islamske godine, prije mjeseca posta Ramazana. Vjerojatno se kao osobno ime nadijeva rođenim u tom mjesecu (usp. Šimunović 2006: 68).

57 Prota je pravoslavni svećenik, a u Alanu žive samo katolici pa nije poznato kako je nastao ovaj nadimak po zanimanju neke osobe.

58 Šoparin je nadimak nastao od riječi šopar > cipelar (postolar) te pripada nadimku koji je osoba dobila po zanimanju. 
kalitetu, kao i osobni nadimci, vremenom su kod nekih krivoputskih obitelji prešli u obiteljske nadimke. Odakle je ili kamo pripada dotična osoba glavni je motiv etničkih nadimaka, kao. npr.:

Bodul, Dalmatinac, Juda, Kanada, Ruskinja ${ }^{59}$, Rus, Talijan, Š́ava ${ }^{60}$, Vugerija ${ }^{61}$ i ̌́vabo. ${ }^{62}$

5. U svakodnevnoj uporabi krivoputskih obiteljski učestali su i nadimci izvedeni prema imenicama iz životinjskog i biljnog svijeta:

Bikan, Bivina, Buva, Buša ${ }^{63}$, Čuk, Fuks ${ }^{64}$, Gavran, Grguš ${ }^{65}, G u d e, G u s i n a^{66}$, Jež, Junac, Kobac ${ }^{67}$, Kos, Kujica, Kurte ${ }^{68}$, Lasica, Lisica, Macin, Mačan, Mačak ${ }^{69}$, Magarac, Medonja, Miš, Papaga ${ }^{70}$, Paun, Pilić, Pile, Purica, Puž, Rilac ${ }^{71}$, Ris, Rojilo, Sokol, Soko, Sova, Srna, Škobac, Telac, Vole, Vranac, Vučina, Vuk, Zekan, Zec, Zvirac, Zekić i Zekonja.

Biljke: Blitva, Bukva, Kapulica, Kupus i Riža.

\section{ZAKLJUČAK}

Cilj ovoga rada bio je popisati krivoputske nadimke, kako bi se otrgnuli od zaborava te evidentirati nekoliko zanimljivih priča vezanih za nastanak pojedinih nadimaka. Također su navedena krivoputska prezimena s objašnjenjima i najčešća osobna muška i ženska imena Krivopućana.

Obiteljski nadimci dio su života, bogatstvo duha ovih ljudi. Oni oslikavaju posebnost pojedinih osoba ili čitavih obitelji te njihovo ponašanje kao i fizičke osobine ljudi koji su po njima prepoznatljivi. Pobliže predstavljaju i oznake obitelji te rodova i plemena. Često svojim sadržajem izražavaju duhovnu, fizičku i satirično-humorističnu karakternu osobinu pojedine osobe, odnosno rodonačelnika obitelji.

Nadimci traju stoljećima dok se imena zaboravljaju. Oni u mnogim slučajevima, a posebice u svakodnevnoj jezičnoj komunikaciji puka preuzimaju identifikacijsku ulogu prezimena, a kod osobnih nadimaka, ulogu imena. Uglavnom su se nadimci davali u slučajevima kada je u određenoj lokalnoj sredini bilo mnogo osoba s istim imenom i prezimenom, što je posebice karakteristično za Krivi Put.

Svi nadimci, kao jezični spomenici prošlosti, čuvaju tajnu svog nastanka pa ih je često veoma teško uvrstiti u neku od jezičnih skupina. Oni, dakle, u sebi sažimaju prošla zbivanja, običaje i život uopće te je u njima pohranjeno sjećanje na mnogobrojne generacije pojedinih obitelji. Osim toga, nadimci su

59 Kazivač Marko Vukelić Mrce, Major iz Alana, r. 1939. kaže: Nadimak Rukinjin dobila je obitelj Butkovića iz Alana, čiji se jedan član, radeći u ondašnjem Sovjetskom Savezu (Rusija) dvadesetih godina 20. soljeća, oženio Ruskinjom, koja je bila plemićkog podrijetla, pa danas njezini potomci nose nadimak Ruskinjini.

60 Sclavonus/ Scavonus> Śćav, Slaven, kako su u Veneciji zvali Hrvate. Više u: Brodnjak 1992: 409.

61 Vuger, Vugri, Vugerija, Ugri> Mađar, Mađari, kao npr. prezimena u sjevernoj Hrvatskoj Vuger ili Ugrin.

Više u: Šimunović 2006: 56.

62 Vjerojatno ovaj nadimak dolazi od hrvatske riječi roj (skupina ili društvo pčela), a za razmnožavanje pčela kažemo da se pčele roje, nastalo od glagola rojiti.

63 Buša je vrsta goveda, krava.

64 Nadimak Fuks (Fuksa) dolazi od njemačke riječi (Fuchsstutte-kobila lisičje boje), a u prenesenom značenju žena probisvijet je kobila. Opširnije u: Klaić 1988: 458.

65 Vrsta ptice.

66 Vjerojatno ovaj nadimak dolazi od riječi gusan, a veliki gusan je gusina.

67 Kobac ili Škobac je vrsta jastreba, a u krivoputskom kraju jastreb grabljivac zove se Kobac.

68 Nadimak Kurte nastao je od turske rijeći kurt>vuk (Šimunović 2006: 401).

69 Mačak je umilan, ali neobljubljen čovjek, onaj koji «grebe» svojim riječima i postupcima.

70 Papagaj, -aja, njem. Papagei, tal. papagallo-papiga, zelena tropska ptica (Klaić 1988: 1002).

71 Imenica rilica ž., rilce, rilo označava izduženi dio glave ili prednjeg dijela tijela kod nekih beskičmenjaka i kralježnjaka (krilca), (Brodnjak 1992: 468). 


\begin{tabular}{|c|c|c|}
\hline \multirow{5}{*}{572859} & - IVAN, MAJORIJA 2, SENJSKA DRAGA. & 764061 \\
\hline & - IVAN, SMILJAN 154, ............ & 678742 \\
\hline & - IVAN, VAGANAC 130, SMILJAN & \\
\hline & - IVAN IVINA, NIKOLE JURISIICA 51 , SENJ & 881 \\
\hline & N I & \\
\hline 572200 & - IVAN KAVARICA, MRZLI DOL $2, \ldots$ & \\
\hline \multirow[t]{2}{*}{572234} & - IVAN-VLADO, I. SENJANINA 21, SENJ & \\
\hline & & \\
\hline & - IVICA, MIROSLAVA KRALJEVIĆA 6, GOSPIC & \\
\hline \multirow{2}{*}{694063} & E & \\
\hline & & \\
\hline & - IVICA, S.S.KRANJČEVIĆA 20, SENJ & \\
\hline & - IVICA, SMILJAN BB, & $678 \leqq$ \\
\hline
\end{tabular}

Slika 3: Suvremena upotreba nadimaka u telefonskom imeniku. Dio imenika sprezimenom Prpić. Iz Telefonskog imenika RH 1999./2000., Knjiga 9, str. 44, izdavač: HT d.d. Zagreb.

neiscrpna riznica jezičnog i povijesnog bogatstva jednog naroda, pa i oni kao i ljudi nastaju, nestaju i zaboravljaju se.

Starost, količina i raznovrsnost obiteljskih i osobnih nadimaka bunjevačkih prezimena krivoputskog kraja, značajna je za istraživanje jezičnih osobina govora te etnogeneze Bunjevaca.

\section{IZVORI:}

Stališ duša /Status Animarum/ Župe Krivi Put, knjiga I, kućni broj 3 do 371. Stališ duša /Status Animarum/ Župe Krivi Put, knjiga II, kućni broj od 371. Stališ duša /Status Animarum/Župe Krivi Put, Knjiga III, Alan i Mrzli Dol

\section{LITERATURA:}

BOGOVIĆ, Mile (1988): Pavlini u Senju. Senjski zbornik, 15: 15-28. Senj. BOGOVIĆ, Mile (1990): Biskup Mirko Ožegović. Senjski zbornik 17:249-260. Senj. BOGOVIĆ, Mile (2008): Župa Krivi Put. U: Živjeti na Krivom Putu. Etnološko-povijesna monografija o primorskim Bunjevcima, 1. svezak, ur. Milana Černelić, Marijeta Rajković, Tihana Rubić, str. 69-75. BRODNJAK, Vladimir (1882): Razlikovni rječnik srpskog i hrvatskog jezika, Školske novine, Zagreb. FELDBAUER, Božidar (2004): Leksikon naselja Hrvatske. sv. I. i II., Zagreb.

FRAS, Franjo Julije (1988): Cjelovita topografija Karlovačke Vojne krajine, Ličke župe, Gospić (pretisak izdanja knjige iz 1835).

HURM, Antun (1959): Njemačko hrvatskosrpski rječnik. Školska knjiga, Zagreb.

KLAIĆ, Bratoljub (1988): Rječnik stranih riječi. Nakladni zavod MH-e, Zagreb.

KORENČIĆ, Mirko (1979): Naselja i stanovništvo SR Hrvatske 1857-1971. Zagreb.

LJUBOVIĆ, Blaženka (2008): Zemljopisni položaj i pregled novije povijesti Krivoga Puta. U: Živjeti na Krivom Putu. Etnološko-povijesna monografija o primorskim Bunjevcima, 1. svezak, ur. Milana Černelić, Marijeta Rajković, Tihana Rubić, str. 49- 68, Zagreb, Senj.

PAVELIĆ, Rikard (1991): Stopa predaka, Bunjevci u Hrvatskom primorju, Gorskom kotaru i Lici. Osobna naklada. Rijeka.

PAVIČIĆ, Stjepan (1962): Seobe i naselja u Lici. Zbornik za narodni život i običaje Južnih Slavena, JAZU, knjiga 41: 5-330, Zagreb.

PAVLIČEVIĆ, Dragutin (1989): Seobe Vlaha Krmpoćana u XII. stoljeću. U: Vojne krajine u jugoslavenskim zemljama u novom veku do Karlovačkog mira 1699, SANU, 147-168, Beograd. 
RAJKOVIĆ, Marijeta (2008.): Selidbe i suživot na ljetnim stanovima. U: Živjeti na Krivom Putu. Etnološko-povijesna monografija o primorskim Bunjevcima, 1. svezak, ur. Milana Černelić, Marijeta Rajković, Tihana Rubić, str. 159-183, Zagreb, Senj.

SALOPEK, Hrvoje (2007): Ogulinsko -modruški rodovi, Matica hrvatska. Ogulin-Hrvatska matica iseljenika - Rodoslovna Udruga P. R. Vitezović, Zagreb.

SEKULIĆ, Ante (2006): Osobna imena, prezimena i nadimci Bačkih Hrvata. Katolički institut za kulturu, povijest i duhovnost Ivan Antunović i NIU Hrvatska riječ, Subotica.

ŠARIĆ, Marko (2008): Bunjevci u ranom srednjem vijeku - postanak i razvoj jedne predmoderne etnije. U: Živjeti na Krivom Putu. Etnološko-povijesna monografija o primorskim Bunjevcima, 1. svezak, ur. Milana Černelić, Marijeta Rajković, Tihana Rubić, str. 15-43, Zagreb, Senj.

ŠIMUNDIĆ, Mate (1988): Rječnik osobnih imena. Nakladni zavod Matice Hrvatske, Zagreb.

ŠIMUNOVIĆ, Petar (2006): Hrvatska prezimena. III. izd., Golden Marketring i Tehnička knjiga, Zagreb.

ZORIČIĆ, Bojan (2006): Nadimci novljanske okolice. U: Vinodolski zbornik 11: 320-331, Crikvenica. ZORIČIĆ, Svetozar (2000): Novljanski nadimci. U: Novljanski zbornik 4:380-388, Novi Vinodolski. 